\title{
Diversity and Threats Encountered by Reptilian Fauna along Cauvery Basin, Kumbakonam, Tamil Nadu, India
}

\author{
Veeramani $\mathrm{A}^{* 1}$ and Pavithra $\mathbf{R}$ \\ ${ }^{1}$ Government Arts College (Autonomous), Kumbakonam, India
}

*Corresponding author: Veeramani Arunachalam, Assistant Professor of Zoology, Government Arts College (Autonomous), Kumbakona -612 002, Tamil Nadu, India, Tel: +91-8124881520, Email: wildveera@gmail.com

\section{Research Article}

Volume 2 Issue 2

Received Date: March 07, 2019

Published Date: March 15, 2019

DOI: $10.23880 /$ izab-16000141

\begin{abstract}
In India, Western Ghats and Eastern Himalayas are rich in herpetofauna. The fascinating ecosystem harbor many endemic herpetofauna. Of the 500 species of reptiles recorded in India, Western Ghats harbour about 156 species and about 93 of them are considered to be endemic to the area. Snakes and other reptile species may prove to be a valuable indicator species in local ecosystems. Hence the present study was taken up to examine the community structure, species richness, diversity and abundance of herpetofauna and to assess the impact on the diversity and density along the Cauvery bank of Kumbakonam region. Visual encountered method was involved searching for herpetofauna in an area or habitat and recording all animals visible on the surface. The opportunistic observations of 11 species of herpetofauna were recorded in the study area includes three species of house lizards, each one species of garden lizard, skink, monitor lizard, 2 species of fresh water turtles and 3 species of snakes. The present study shows that the distribution of reptiles in Cauvery basin of Kumbakonam region is largely determined by temperature, microhabitat availability and various geophysical constraints. Habitat alterations is impacted almost all endemic reptile species of the area.
\end{abstract}

Keywords: Diversity; Reptiles, Snakes; Cauvery Basin; Opportunistic Survey

\section{Introduction}

Reptiles are cold-blooded animals found in almost all the parts of the world, except the severe colder regions. In India, all the three living orders of reptiles have their representatives - Crocodylia (crocodiles), Testudines (turtles and tortoises) and Squamata (lizards and snakes). An updated checklist of 518 species of reptiles which includes 3 species of crocodiles, 34 species of turtles and tortoises, 202 species of lizards and 279 species of snakes belonging to 28 families recorded till date from India [1]. The diversified climate, varying vegetation and different types of soil in the country form a wide range of biotopes that support a highly diversified reptilian fauna. The Western Ghats, Eastern Himalaya, and the Andaman and Nicobar Islands are endowed with varied and unique reptilian fauna [2]. 


\section{International Journal of Zoology and Animal Biology}

The monumental works on Indian reptiles are, 'The Reptiles of British India' by Gunther, et al. [3], 'Fauna of British India - 'Reptilia and Batrachia' by Boulenger, et al. [4] and Smith, et al. [5-7]. The work of Smith stood the test of time and forms the standard work on the subject. Further contributions were made by Tiwari et al. [8], Sharma [9-14], Murthy [15-17], Das [18-22], Tikedar, et al. [23], Das et al. [24], Das, et al. [25], Daniel [26], Whitaker, et al. [27], Sharma [14], Thrope, et. al. [28], Mukherjee, et al. [29], Gower, et al. [30], Manamendra-Arachchi, et al. [31], Das, et al. [32], Giri [33], Giri, et al. [34], Giri, et al. [35], Giri, et al. [36], Zambre et al. [37], Haralu [38], Pook, et al. [39], Van Rooijen, et al. [40], Mahony S [41,42].

In India, Western Ghats and Eastern Himalayas are rich in herpetofauna. The fascinating ecosystem harbor many endemic herpetofauna. Of nearly 500 species of reptiles in India, Western Ghats harbour about 156 species and about 93 of them are considered to be endemic to the area [43-45]. Aengals, et al. [46] mentions 12 species of reptiles as endangered. The altitude, climatic gradients support and nourish different species of herpetofauna. They are distributed in a wide variety of habitats ranging from rain forest to desert and almost found in all niches from rock crevices to tree bark. Some of them are endemic to particular habitat and some of them are very common, found throughout the hills country. Amphibians and reptiles render incalculable services to agriculture. Insects occupy first place amongst pest that damage standing crops. Majority of frogs and lizards feed on insects which are destroying the crops and forest ecosystem. Snakes have an irreplaceable role in ecology as the natural predators of rats and agricultural pests. Particularly in predominantly agricultural economies like India, the burgeoning rodent population, made worse by human overcrowding, proliferation of garbage and our unhygienic habits, has become one of the greatest scourges.

Snakes are singularly designed and equipped to hunt for rats in their narrow subterranean burrows and hiding places in the open and in the granaries, storages etc. Similarly, those snakes which regularly feed on insects have been responsible for destroying vast number of insects which are pests in our ecosystem. These groups of animals are mostly nocturnal in nature and some of them are active round the clock. They render great service by exterminating nocturnal and diurnal insects. The significance of amphibians and reptiles for the biosphere of our planet consequently to mankind, is so great that it is difficult to equate it with that of another group of organisms. Snakes and other reptiles may prove to be a valuable indicator species in local ecosystems. These groups of animals are mostly nocturnal in nature and some of them are active round the clock. They render great service by exterminating nocturnal and diurnal insects. The significance of amphibians and reptiles for the biosphere of our planet consequently to mankind, is so great that it is difficult to equate it with that of another group of organisms. Snakes and other reptiles may prove to be a valuable indicator species in local ecosystems.

However, extensive loss and fragmentation of tropical forests in the past several decades have set the stage for an extinction crisis in the near future as remnant fragments undergo further fragmentation and degraded forests shed species more rapidly [47]. Recent thrust on biodiversity conservation necessitates a comprehensive knowledge of the fauna, their distribution and abundance that are important prerequisites for the management of an area, especially in the Cauvery basin areas. Currently, Habitat fragmentation is a primary cause of decline for many species of wildlife particularly the herpetofauna. Hence the present study was taken up to examine the community structure, species richness, diversity and abundance of herpetofauna and to assess the impact on the diversity and density along the Cauvery bank of Kumbakonam region.

\section{Materials and Methods}

The Cauvery delta is usually hot; the climate of Kumbakonam and other surrounding towns is generally healthy and moderate. Kumbakonam is cooler than Chennai, the capital of Tamil Nadu. The maximum temperature in summer is about $40^{\circ} \mathrm{C}$ while the minimum temperature is about $20^{\circ} \mathrm{C}$. Kumbakonam receives an annual rainfall of $114.78 \mathrm{~cm}$ every year. The region is covered with mainly alluvial or black soil which is conducive for paddy cultivation. Other crops grown in Kumbakonam include mulberry, cereals and sugarcane (Figure 1).

The study was conducted during the period between December 2017 and March 2018 along the river banks, ponds, agricultural fields, wood lands and abandoned buildings, etc. with the following methods.
Veeramani A and Pavithra R. Diversity and Threats Encountered by Reptilian Fauna along Cauvery Basin, Kumbakonam, Tamil Nadu, India. Int J Zoo Animal Biol 2019, 2(2): 000141.
Copyright(C) Veeramani A and Pavithra R. 


\section{International Journal of Zoology and Animal Biology}

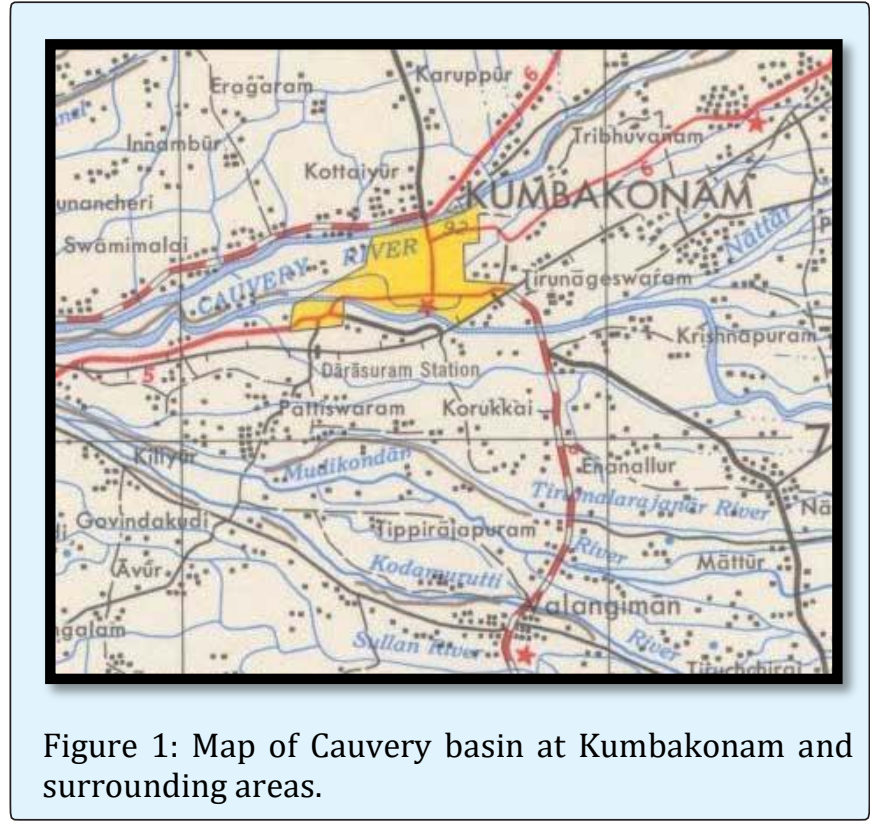

\section{Visual Encounter Survey}

This method involved searching for herpetofauna in an area or habitat and recording all animals visible on the surface $[48,49]$. While walking on the field, scanned the vegetation path, and other possible places for the recordings the species observed from the path. Often, searched the leaf litter as semi fossorial species emerge slightly disturbed which allowed them to be recorded. The animal thus found is recorded in the data sheet such as species, time of the day, area, vegetation's, altitude and location of the herpetofauna above the ground. Actual site of the herpetofauna when first observed was descriptively noted and later classified in to various micro habitats such as tree trunk, ground, leaf litter and rock. Sex, color variation, height from ground upon sighting, micro habitat, injuries, defects presence of ecto parasites, threats (Presence of predators, habitat changes, etc) were also noted. The sampling duration in each locality was largely depending up on the size of the area.

The raw data which were collected in the study area were pooled together for statistical analysis. Herpetofaunal density was estimated by using the simple formula:

Relative density $=\frac{\text { No. of Individuals of a species }}{\text { Total No. of individuals of all species }} \times 100$

\section{Results}

Three species of house lizards, each one species of garden lizard, skink, monitor lizard, 2 species of fresh water turtles and 3 species of snakes were identified and recorded. Photographs were taken for identification (Figures 2 \& 3). The opportunistic observations of 11 species of herpetofauna were recorded in the study area are given in Table 1.

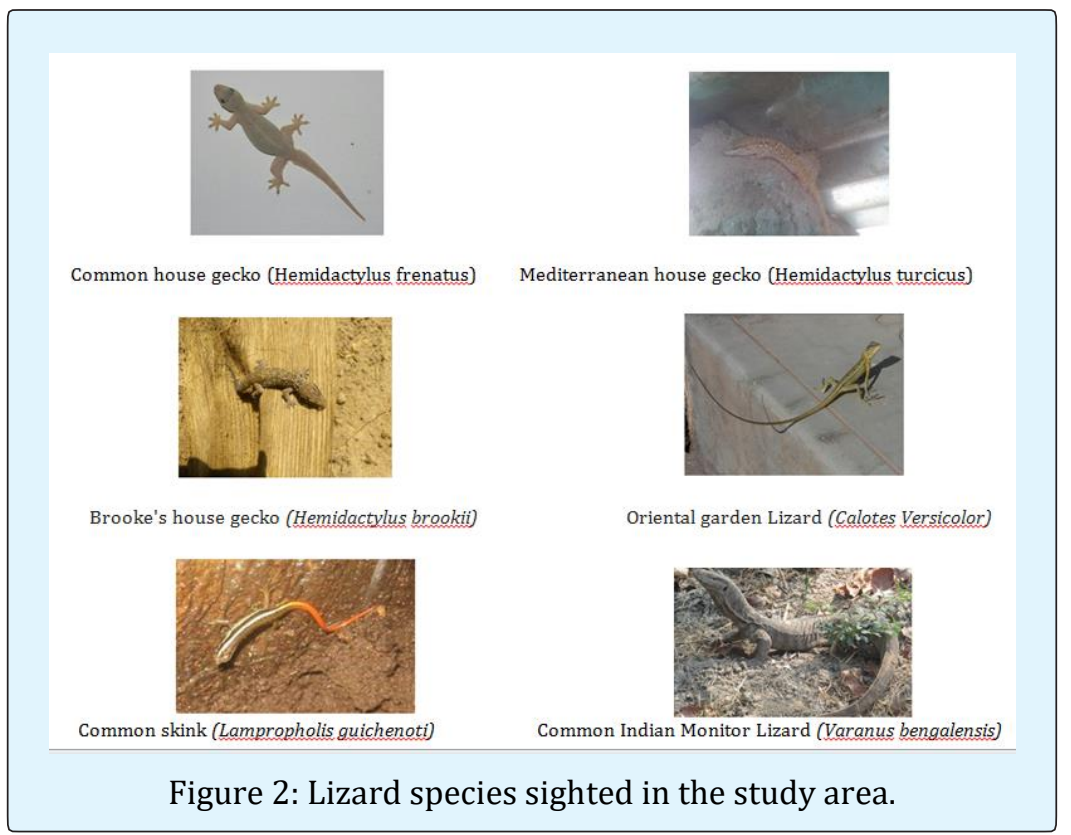

Veeramani A and Pavithra R. Diversity and Threats Encountered by Reptilian Fauna along Cauvery Basin, Kumbakonam, Tamil Nadu, India. Copyright@ Veeramani A and Pavithra R. Int J Zoo Animal Biol 2019, 2(2): 000141. 


\section{International Journal of Zoology and Animal Biology}

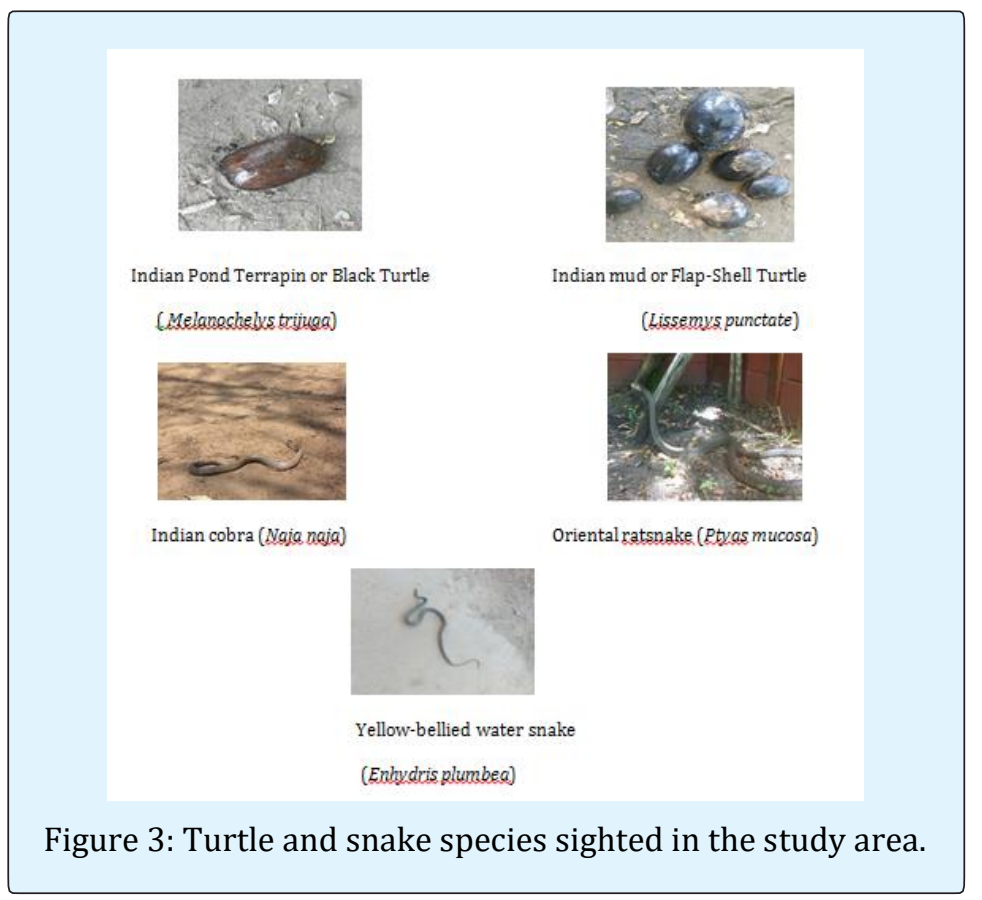

\begin{tabular}{|c|c|c|c|c|}
\hline Sl. No. & Common Name & Scientific Name & $\begin{array}{c}\text { Number of individuals } \\
\text { sighted }\end{array}$ & Relative density \\
\hline 1 & $\begin{array}{c}\text { Indian Pond Terrapin or Black } \\
\text { Turtle }\end{array}$ & Melanochelys trijuga & 2 & 3 \\
\hline 2 & Indian mud or Flap-Shell Turtle & Lissemys punctate & 1 & 2 \\
\hline 3 & Common house gecko & Hemidactylus frenatus & 23 & 37 \\
\hline 4 & Mediterranean house gecko & Hemidactylus turcicus & 7 & 5 \\
\hline 5 & Brooke's house gecko & Hemidactylus brookii & 3 & 29 \\
\hline 6 & Oriental garden lizard & Calotes versicolor & 18 & 3 \\
\hline 7 & Common skink & Lampropholis guichenoti & 2 & 3 \\
\hline 8 & Common Indian Monitor Lizard & Varanus bengalensis & 2 & 2 \\
\hline 9 & Oriental ratsnake & Ptyas mucosa & 1 & 3 \\
\hline 10 & Yellow-bellied water snake & Enhydris plumbea & 2 & 2 \\
\hline 11 & Indian cobra & Naja naja & 1 & \\
\hline
\end{tabular}

Table 1: Reptiles recorded during the study period.

\section{Diversity Indices}

The diversity index of the reptiles species recorded is given in the Table 2 . Among the 11 species of reptiles recorded a total of 62 individuals were noted and the Dominance of reptiles shows 0.2419 with a lower and upper limits of $0.1899 \pm 0.334$. The Simson index of 0.7581 with lower and upper limits of $0.6649 \pm 0.8091$ and the Shannon diversity index of 1.763 with lower and upper limits of $1.377 \pm 1.934$ (Table 2 \& Figure 4).
Veeramani A and Pavithra R. Diversity and Threats Encountered by Reptilian Fauna along Cauvery Basin, Kumbakonam, Tamil Nadu, India. Int J Zoo Animal Biol 2019, 2(2): 000141.

\begin{tabular}{|c|c|c|c|}
\hline & & Lower & Upper \\
\hline Taxa_S & 11 & 7 & 11 \\
\hline Individuals & 62 & 62 & 62 \\
\hline Dominance_D & 0.2419 & 0.1899 & 0.334 \\
\hline Simpson_1-D & 0.7581 & 0.6649 & 0.8091 \\
\hline Shannon_H & 1.763 & 1.377 & 1.934 \\
\hline Evenness_e^ $\mathrm{A} / \mathrm{H}$ & 0.5297 & 0.4711 & 0.6974 \\
\hline
\end{tabular}

Table 2: Diversity indices of the reptile species sighted. 


\section{International Journal of Zoology and Animal Biology}

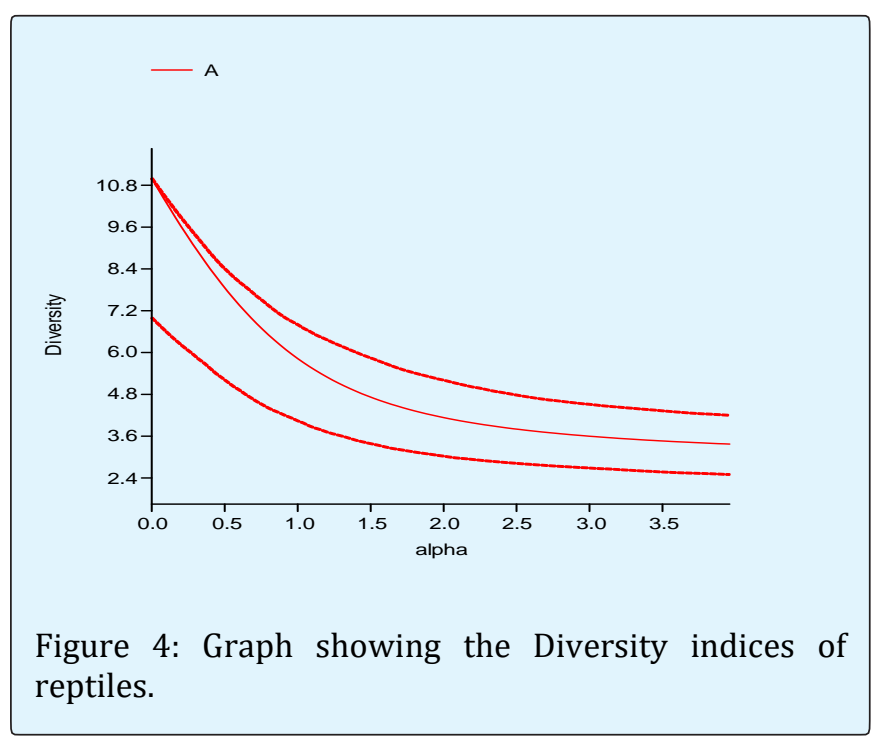

\section{Discussion}

A total of eleven species of reptiles were sighted shows the less number of species available in the study area. This may be due to the destruction of micro habitats of the reptilian fauna. Lizards of the study area include 3 species of Geckos, one species of Skink, Garden lizard and Monitor lizard. Two species of fresh water turtles and three species of snakes are recorded. When interviewed to the local residents that they opined many species of lizards were disappeared from the area in the near past such as Chamaleon zeylanicus and many other lizard species are decreasing sharply. They also mentioned that abundance of bricks choolas, intentional killing of snakes when they appeared, poisoning of crops, construction of buildings, etc. were the major reasons for depletion of reptilian fauna in the Cauvery basin regions. Similarly the increasing human population of India has produced increased development and road networks that have brought worrying pressure on populations of flora and fauna in its biodiversity. The study area has experienced massive changes over the last decades with the development of plantations and towns. This has led to increased vehicle traffic and the subsequent increase in mortality of reptiles and amphibians on roads [50]. Similar reports in the Western Ghats are also under threat from habitat loss and fragmentation, as well as intensive harvesting of non-timber products, hunting, invasive species and grazing by livestock [51-54].

The large numbers of reptile species known from the Western Ghats, some of which are described in this study area, combined with the large numbers of species still being described, highlight the need for a more concerted scientific study of the Cauvery delta region as well as a need for greater protection of the habitat that remains.

\section{Conclusion}

Based on these significant additions of species to the existing picture, the study further emphasize the prioritization of this habitat from a conservation perspective. This study indicated that the area rich and must contain many more species of reptiles. It is recommended that further studies in the Cauvery basin at the earliest warranted. Also everyone should realize that the protection of habitat is an important aspect in the conservation of such species. The present study shows that the distribution of reptiles in Cauvery basin of Kumbakonam region is largely determined by temperature, microhabitat availability and various geophysical constraints. Habitat alterations is impacted almost all endemic reptile species of the area. Regarding their food habits, lizards were more opportunistic feeders than snakes. Niche analysis showed that the reptiles of this region have low to moderate survival capabilities with respect to utilization of various spatio-temporal and trophic resources.

This work has made fairly good progress in the tenure that it was proposed for a short period. Yet the work needs more time before any strong conclusion can be reached. All information provided in this work are preliminary and baseline data that need further work in future for designing any strong conservation policies involving the farmers of these areas.

\section{References}

1. Aengals R, Kumar SVM, Palot MJ (2012) Updated Checklist of Indian Reptiles. Zoological survey of India, pp: 1-24.

2. Kanaujia A, Kumar A, Kumar A (2017) Herpetofauna of Uttar Pradesh, India. Biological Farum-An Int Journal 9(1): 118-130.

3. Gunther, CLC Albert (1864) The Reptiles of British India. Published by Oxford \&IBH Publishing Co. New Delhi, pp: 452.

4. Boulenger GA (1890) The fauna of British India including Ceylon and Burma: Reptilia and Batrachia, pp: 541 . 


\section{International Journal of Zoology and Animal Biology}

5. Smith MA (1935) The Fauna Of British India Including Ceylon And Burma Reptilia and Amphibia Vol-ii Sauria.

6. Smith MA (1935) The Fauna of British India including Ceylon and Burma. Reptilia and Amphibia, VolI. Loricata, Testudines. Taylor and Francic, London.

7. Smith MA (1943) The Fauna of British India including Ceylon and Burma. Reptilia and Amphibia, VolI. Loricata, Testudines, Taylor and Francic, London.

8. Tiwari K, Biswas S (1973) Two new reptiles from the Great Nicobar Island. Journal of Zoological Society of India 25(1\&2): 57-63.

9. Sharma RC (1977) A new lizard of the genus Riopa Gray (Scincidae) from Tamil Nadu, India. Records of the Zoological Survey of India 73(1-4): 41-44.

10. Sharma RC (1978) A new species of Phrynocephalus Kaup (Reptilia: Agamidae) from the Rajasthan desert India with notes on its ecology. Bulletin of the Zoological Survey of India 1(3): 291-294.

11. Sharma RC (1981) Hemidactylus porbandarensis a new geckonid lizard from Gujarat India. Bulletin of the Zoological Survey of India 4(1): 1-2.

12. Sharma RC (1998) Fauna of India and the adjacent countries. Reptilia (Testudines and Crocodilia). Volume I. Published by the Director, Zoological Survey of India, Kolkata, pp: 196.

13. Sharma RC (2002) The fauna of India and the adjacent countries. Reptilia (Sauria). II, Published by the Director, Zoological Survey of India, Kolkata, pp: 430.

14. Sharma R C (2007) The fauna of India and the adjacent countries. Reptilia (Serpentes) -111 Published by the Director, Zool Surv India, Kolkata, pp: 410.

15. Murthy TSN (1985) Classification and distribution of the Reptiles of India. The Snake 17: 48-71.

16. Murthy TSN (1994) An updated hand list of the reptiles of India. Cobra 17: 17-37.

17. Murthy TSN (2010) The Reptile Fauna of India. Published by B.R. Publishing Corporation, New Delhi.
18. Das I (1991) A new Species of Mabuya from Tamil Nadu State southern India (Squamata: Scincidae). Journal of Herpetology 25(3): 342-344.

19. Das I (1994) The reptiles of south Asia Checklist and distribution summary. Hamadryad 19: 15-40.

20. Das I (1996) Biogeography of the Reptiles of South Asia. Published by Krieger Publishing Company, Malabar.

21. Das I (1997) Checklist of the Reptiles of India with English Common name. Hamadryad. 22(1): 32-45.

22. Das I (2003) Growth of Knowledge on the Reptiles of India, with an Introduction to Systematics, Taxonomy and Nomenclature. J Bombay nat Hist Soc 100(2\&3): 447-501.

23. Tikedar BK, Sharma RC (1992) Handbook of Indian Reptiles. Zoological Survey of India, Kolkota.

24. Das I, Bauer AM (2000) Two new species of Cnemaspis (Sauria: Gekkonidae) from Tamil Nadu, Southern India. Russian Journal of Herpetology 7(1): 17-28.

25. Das I, Sengupta S (2000) A new species of Cnemaspis (Sauria: Gekkonidae) from Assam northeastern India. Journal of South Asian Natural History 5(1): 17-24.

26. Daniel JC (2002) The Book of Indian Reptiles. Bombay Natural History Society, Bombay, pp: 141.

27. Whitaker R, Captain A (2004) Snakes of India - The Field Guide. Draco Books, Chennai, pp: 481.

28. Thorpe RS, Pook CE, Malhotra A (2007) Phylogeography of the Russell's viper (Daboia russelii) complex in relation to variation in the colour pattern and symptoms of envenoming. The Herpetological Journal 17(4): 209-218.

29. Mukherjee D, Bhupathy S (2007) A new species of wolf snake (Serpentes: Colubridae: Lycodon) from Anaikatti Hills, Western Ghats, Tamil Nadu, India. Russian Journal of Herpetology 14(1): 21- 26.

30. Gower DJ, Winkler JD (2007) Taxonomy of the Indian snake Xylophis Beddome (Serpentes: Caenophidia) with description of a new species. Hamadryad 31(2): 315-329. 


\section{International Journal of Zoology and Animal Biology}

31. Manamendra Arachchi K, Batuwita S, Pethiyagoda R (2007) A taxonomic revision of the Sri Lankan daygeckos (Reptilia: Gekkonidae: Cnemaspis), with description of new species from Sri Lanka and southern India. Zeylanica 7(1): 9-122.

32. Das I, Vijayakumar SP (2009) New species of Ptychozoon (Sauria: Gekkonidae) from the Nicobar Archipelago, Indian Ocean. Zootaxa 20(95): 8-20.

33. Giri VB (2008) A new rock dwelling Hemidactylus (Squamata: Gekkonidae) from Maharashtra, India. Hamadryad 32: 25-34.

34. Giri VB, Bauer AM (2008) A new ground-dwelling Hemidactylus (Squamata: Gekkonidae) from Maharashtra, with a key to the Hemidactylus of India. Zootaxa 1700: 21-34.

35. Giri VB, Bauer AM, Vyas R, Patil S (2009a) New Species of Rock-Dwelling Hemidactylus (Squamata: Gekkonidae) from Gujarat, India. Journal of Herpetology 43(3): 385-393.

36. Giri VB, Bauer AM, Gaikwad KS (2009b) A new ground-dwelling species of Cnemaspis Strauch (Squamata: Gekkonidae) from the northern Western Ghats, Maharashtra, India. Zootaxa 2164: 49-60.

37. Zambre A, Sheth C, Dalvi S, Kulkarni N (2010) First Record Of Protobothrops jerdoni xanthomelas (Günther, 1889) From Eaglenest Wildlife Sanctuary, India. J Bombay Nat Hist Soc 106 (2): 211-213.

38. Haralu B (2010) Nagaland concerns and challenges. Indian Birds 6(2): 56-57.

39. Pook CE, Joger U, Stümpel N, Wüster W (2009) When continents collide: Phylogeny, historical biogeography and systematic of the medically important viper genus Echis (Squamata: Serpentes: Viperidae). Mol Phylogenet Evol 53(3): 792-807.

40. Van Rooijen J, Vogel G (2009) A multivariate investigation into the population systematics of Dendrelaphis tristis (Daudin, 1803) and Dendrelaphis schokari (Kuhl,1820): revalidation of Dendrophis chairecacos Boie, 1827 (Serpentes: Colubridae). The Herpetological Journal 19: 193-200.

41. Mahony S (2009) A New Species of Gecko of the Genus Hemidactylus (Reptilia: Gekkonidae) from
Andhra Pradesh, India. Russian Journal of Herpetology 16(1): 27-34.

42. Mahony S (2010) Systematic and taxomonic revaluation of four little known Asian agamid species, Calotes kingdonwardi Smith, 1935, Japalura kaulbacki Smith, 1937, Salea kakhienensis Anderson, 1879 and the monotypic genus Mictopholis Smith, 1935. (Reptilia: Agamidae). Zootaxa 2514(1): 1-23.

43. Murthy TSN (1992) An updated systematic index and bibliography of the reptiles of the Western Ghats. India. Rec Zool Surv India 91(2): 169-180.

44. Swengel FB (1990) A checklist of endemic vertebrates of the Western Ghats region. Nilgiri Tahr. North American Regional stud Book. Minnesota Zoological garden. USA, pp: 4-13.

45. Swengel FB (1993) Endemic vertebrates of the of the Western Ghats region- An update. Nilgiri Tahr. North American Regional stud Book update. Minnesota Zoological garden. USA 12-13.

46. Aengals R (1996) Captive breeding of Reptiles at the Madras Snake Park. Cobra 24: 13-15.

47. Brooks TM, Mittermeier RA, Mittermeier CG, da Fonseca, Rylands GAB, et al. (2002) Habitat loss and extinction in the hotspots of biodiversity. Conserv Biol 16(4): 909-923.

48. Campbell HW, Christman SP (1982) Field techniques for herpetofaunal community analysis. In: Scott NJ, (Eds.), Herpetological Communi- ties, US Fish. Wildl Serv Wildl Res Rep 13: 193-200.

49. Corn PS, Bury RB (1990) Sampling methods for terrestrial amphibians and reptiles. In: Carey AC, Ruggier LF (Eds.), Wildlife-Habitat Rela- tionships: Sampling Procedures for Pacific North- west Vertebrates, pp: 1-28.

50. Vijayakumar SP, Vasudevan K, Ishwar NM (2001) Herpetofaunal mortality on roads in the Anamalai hills, southern Western Ghats. Hamadryad 26: 265272.

51. Vasudevan K, Kumar A, Chellam R (2001) Structure and composition of rainforest floor amphibian communities in Kalakad- Mundanthurai Tiger Reserve. Curr Sci 80(3): 406-412. 


\section{International Journal of Zoology and Animal Biology}

52. Davidar P, Arjunan M, Mammen PC, Garrigues JP, Puyravaud JP, et al. (2007) Forest degradation in the Western Ghats biodiversity hotspot: resource collection, livelihood concerns and sustainability. Curr Sci 93(11): 1573-1578.

53. Gunawardene NR, Dulip Daniels AE, Gunatilleke IAUN, Gunatilleke CVS, Karunakaran PV, et al. (2007)
Brief overview of the Western Ghats - Lanka biodiversity hotspot. Curr Sci 93(11): 1567-1572.

54. Venugopal PD (2010) Addentum to An updated and annotated list of Indian lizards (Reptilia: Sauria) based on a review of distribution records and checklists of Indian Reptiles. Journal of Threatened Taxa 2(4): 848. 